УДК 342.4

DOI https://doi.org/10.32849/2663-5313/2020.7.38

Олена Сінькевич,

канд. юрид. наук, доцент,

доцент кафедри конституиійного права

юридичного факультету

Київського національного університету імені Тараса Шевченка

\title{
РЕГУЛЯТИВНА ФУНКЦІЯ ГАЛУЗІ КОНСТИТУЦІЙНОГО ПРАВА УКРАЇНИ: СУЧАСНІ ТЕНДЕНЦІї
}

У статті проаналізовано регулятивну функцію галузі конституиійного права України, насамперед сучасні проблеми ї реалізачії. До внутрішніх функиій права, які відображають його змістовний вплив на суспільні відносини, слід віднести регулятивну та охоронну функиї. Коли дослідники згадують про иі функиї, вони завжди розмішують їх саме в такому порядку - спочатку йдеться про регулятивну, а вже потім - про охоронну функиію.

Важливість регулятивної функиї права важко переоцінити, $і$ галузь конституиійного права України не є винятком. Регулятивну функиію зовсім не випадково «висувають» на перше місие в переліку, який охоплює охоронну функиію права, а інколи й деякі інші. Адже право традииійно називають регулятором суспільних відносин, $і$ ие надає підстави акцентувати увагу саме на регулятивній його функиї.

Враховуючи важливість норм галузі конституційного права Украӥни для розвитку національної правової системи, слід наголосити на тому, що регулятивна функиія в контексті досліджуваної галузі є більш важливою, ніж охоронна. На мою думку, ие пов'язано з низкою аргументів, основним серед яких є такий, що необхідно продовжувати вказувати на відмову України від тоталітарного минулого, на поступові та постійні зусилля всіх органів публічної влади, які спрямовуються в напрямі демократизачї державного життя.

На прикладі законопроектної діяльності (політична партія «Слуга народу» подала до Верховної Ради України Проект Закону про внесення змін до Закону України «Про правонаступництво України» щодо скасування дії актів СРСР та УРСР на території України під реєстраиійним номером 1075 від 29 серпня 2019 року) виявлено, як саме запровадити послідовну, без протиріч, реалізаиію иієї функиї в контексті дотримання всіх сучасних иінностей конституиійного права України зокрема та сучасного украӥнського конституиіоналізму загалом.

Навряд чи регулятивна функиія конституиійного права може бути повноиінно виконана, оскільки вагома частина нормативно-правових актів, положення яких регламентують низку інститутів иієї галузі, була прийнята зовсім в інших історичних умовах, ніж нинішні, з урахуванням інших иінностей конституиіоналізму.

Перспективи подальших досліджень вбачаю в посиленні аргументаиї провідного характеру регулятивної функцї̈ галузі конституційного права України у порівнянні з його охоронною функцією.

Ключові слова: конституційне право, конституційне право як галузь права, конституціоналізм, функції конституційного права, галузеві функції, функції права, регулятивна функція.

Постановка проблеми. До внутрішніх функцій права, які відображають його змістовний вплив на суспільні відносини, слід зарахувати регулятивну та охоронну функції. Коли дослідники згадують про ці функції, вони завжди розміщують їх саме в такому порядку - спочатку йдеться про регулятивну, а вже потім - про охоронну функцію.

Аналіз останніх досліджень і публікацій. Найбільш активно регулятивну функцію досліджували фахівці з теорії держави і права (O.I. Абрамов, T.M. Радько та інші). У працях українських вчених-конституці- оналістів це питання знайшло свою постановку лише у фрагментах статей в наукових фахових виданнях $[1 ; 2 ; 3 ; 4]$.

Метою статті $\epsilon$ проаналізувати регулятивну функцію галузі конституційного права України, насамперед сучасні проблеми її реалізації.

Виклад основного матеріалу. При визначенні поняття «регулятивна функція права» дослідники керуються своїми розробками щодо дефініції поняття «функція права». 3 урахуванням дуалістичної сут- 
ності функцій права найбільш прийнятними є такі пропозиції фахівців 3 теорії держави і права:

1) «регулятивна функція права - це визначений соціальним (класовим) призначенням основний напрям його впливу на суспільні відносини, який здебільшого виявляється у встановленні позитивних правил поведінки, представлених позитивних прав та активних обов'язків суб'єктам права» [5] (Т.М. Радько);

2) «регулятивна функція права $є$ внутрішньо властивим праву явищем, зумовленим роллю (призначенням) права в суспільстві як регулятора соціального життя, що є таким напрям впливу права на суспільні відносини, який покликаний забезпечити певний рівень їх соціальної впорядкованості, найбільш повно виражає сутність права, а також його взаємозв'язок з іншими явищами соціальної дійсності» [6] (О.І. Абрамов).

Важливість регулятивної функції права важко переоцінити, і галузь конституційного права України не є винятком. Регулятивну функцію зовсім не випадково «висувають» на перше місце у переліку, який охоплюе і охоронну функцію права, а інколи і деякі інші. Адже право традиційно називають регулятором суспільних відносин, і це дає підстави акцентувати увагу саме на регулятивній його функції.

Враховуючи важливість норм галузі конституційного права України для розвитку національної правової системи, слід наголосити на тому, що регулятивна функція в контексті досліджуваної галузі є більш важливою, ніж охоронна функція. На мою думку, це пов'язано з низкою аргументів, основним серед яких є такий, що необхідно продовжувати вказувати на відмову України від тоталітарного минулого, на поступові та постійні зусилля всіх органів публічної влади, які спрямовуються на демократизацію державного життя.

Здавалося б, Україна проголосила незалежність від СРСР ще в 1991 році. Акт проголошення незалежності України від 24 серпня 1991 року передбачає у своєму передостанньому абзаці, що:

«Віднині на території України мають чинність виключно Конституція і закони України» [7].

Акт проголошення незалежності України було затверджено постановою Верховної Ради Української РСР від цієї ж дати. Зокрема, у цій постанові йшлося про таке:

«Верховна Рада Української Радянської Соціалістичної Республіки постановляє:

Проголосити 24 серпня 1991 року Україну незалежною демократичною державою.
3 моменту проголошення незалежності чинними на території України $є$ тільки iï Конституція, закони, постанови Уряду та інші акти законодавства республіки» [8].

Однак ці положення було деталізовано через кілька місяців у Законі України від 12 вересня 1991 року «Про правонаступництво України». У цьому законі питанням правонаступництва у сфері нормативно-правових актів приділялася більш чільна увага, зокрема зазначалося:

«Стаття 2. До ухвалення нової Конституції України на території України діє Конституція (Основний Закон) Української РСР.

Стаття 3. Закони Української РСР та інші акти, ухвалені Верховною Радою Української РСР, діють на території України, оскільки вони не суперечать законам України, ухваленим після проголошення незалежності України» [9].

Встановлені у 1991 році положення залишаються актуальними і нині. Здавалося б, що після зміни державного режиму 3 антидемократичного на демократичний увага мала б приділятися оновленню законодавства з урахуванням нових конституційних цінностей. Однак відповідні процеси спочатку були активними, а згодом загальмувалися.

Гальмування процесів оновлення законодавства радянських часів було настільки істотним, що привернуло увагу політичної еліти. Так, влітку 2019 року політична партія «Слуга народу» подала до Верховної Ради України Проект Закону про внесення змін до Закону України «Про правонаступництво України» щодо скасування дії актів СРСР та УРСР на території України, реєстраційний № 1075 від 29 серпня 2019 року. Пояснювальна записка до проекту Закону № 1075 від 29 серпня 2019 року містить низку цікавих питань з точки зору досліджуваної проблеми функцій галузі конституційного права загалом та регулятивної галузевої функції зокрема.

Першим важливим питанням, на якому слід наголосити в контексті дослідження тексту Пояснювальної записки, є питання належної термінології в частині конституційно-правових питань. Так, у частині 6 «Прогноз соціально-економічних та інших наслідків прийняття проекту Закону» йдеться про те, що внаслідок прийняття цього проекту закону України буде забезпечено, зокрема, «конституційне право кожного знати свої права та обов'язки» [10]. Варто підкреслити, що це - не суб'єктивне конституційне право, а одна з конституційних гарантій прав людини. Слід зауважити, що такі неточності навряд чи є припустимими у законотворчій діяльності. 
Друге важливе питання, про яке згадується у Пояснювальній записці, - це питання природнього «розділу» хронологічного характеру актів національного позитивного права. Так, автори Пояснювальної записки стверджують, що станом на літо 2019 року цей поділ має такий вигляд:

1) акти органів державної влади і управління СРСР та УРСР;

2) законодавство України.

Слід погодитися з такою констатацією та зазначити, що в Пояснювальній записці наведений перелік найважливіших актів, які належать до першої групи та є чинними. Автори проекту визнали їх найважливішими тому, що пропонують спеціальні положення щодо них - не скасування в разі набуття чинності пропонованим законом (після його прийняття), а особливий характер дії у часі. Йдеться про два кодекси (Житловий кодекс Української РСР (Відомості Верховної Ради УРСР, 1983 рік, додаток до № 28, ст. 573) та Кодекс України про адміністративні правопорушення (Відомості Верховної Ради УРСР, 1984 рік, додаток до № 51, ст. 1122), а також про закони, до яких автори проекту пропонують вважати належними:

«1) Закон України «Про пріоритетність соціального розвитку села та агропромислового комплексу в народному господарстві» (Відомості Верховної Ради УРСР, 1990 , № 45, ст. 602);

2) Закон України «Про правовий режим території, що зазнала радіоактивного забруднення внаслідок Чорнобильської катастрофи» (Відомості Верховної Ради УРСР, 1991, № 16, ст. 198);

3) Закон України «Про захист прав споживачів» (Відомості Верховної Ради УРСР, 1991, № 30, ст. 379);

4) Закон України «Про основи соціальної захищеності осіб з інвалідністю в Україні» (Відомості Верховної Ради УРСР, 1991, № 21, ст. 252);

5) Закон України «Про реабілітацію жертв репресій комуністичного тоталітарного режиму 1917-1991 років» (Відомості Верховної Ради УРСР, 1991, № 22, ст. 262);

6) Закон України «Про свободу совісті та релігійні організації» (Відомості Верховної Ради УРСР, 1991, № 25, ст. 283);

7) Закон України «Про зовнішньоекономічну діяльність» (Відомості Верховної Ради УРСР, 1991, № 29, ст. 377);

8) Закон України «Про охорону навколишнього природного середовища» (Відомості Верховної Ради України, 1991, № 41, ст. 546);

9) Закон України «Про індексацію грошових доходів населення» (Відомості Верховної Ради України, 1991, № 42, ст. 551)» [11].
На думку авторів проекту Закону № 1075 від 29 серпня 2019 року, закони із наведеного переліку мають діяти «тимчасово, до прийняття законів України, що регулюють відповідні відносини» [11], так само як і ті підзаконні нормативно-правові акти, які були прийняті на їх виконання.

Загалом варто погодитися з логікою авторів проекту Закону № 1075 від 29 серпня 2019 року в частині того, що варто позбутися такого, який вони констатували, «поділу» національного законодавства на частини. Очевидно, що прийняті за часів Української РСР нормативні акти, багато з яких стосується таких важливих інститутів конституційного права, як права людини, громадянське суспільство, інших, грунтуються на принципах, встановлених за умов тоталітарного державного режиму. Ідеологія була іншою, функції держави були іншими, тому й функції права та функції галузі конституційного права були іншими.

Неможливість поступового, еволюційного повного оновлення національного законодавства викликала ідею цього проекту Закону, який пропонує провести таке оновлення здебільшого одномоментно, революційно. Так, проектом Закону № 1075 від 29 серпня 2019 року передбачено:

1) визнати такою, що втратила чинність, постанову Верховної Ради України від 12 вересня 1991 року 1545-XII «Про порядок тимчасової дії на території України окремих актів законодавства Союзу РСР» [12];

2) внести зміни та доповнення у статтю 3 Закону України від 12 вересня 1991 року «Про правонаступництво України».

Статтю 3 вказаного нормативно-правового акту запропоновано викласти у такій редакції:

«Стаття 3. Закони та інші акти органів державної влади і управління Союзу PCP та Української РСР, крім Декларації про державний суверенітет України від 16 липня 1990 року, Акта проголошення незалежності України від 24 серпня 1991 року, актів, що стосуються адміністративно-територіального устрою України та державного кордону України, актів, якими надано згоду на обов'язковість міжнародних договорів, укладених Українською РСР, актів організаційно-розпорядчого характеру та індивідуальних актів, не діють на території України» [11].

Дійсно, навряд чи регулятивна функція конституційного права може бути повноцінно виконана, коли більша частина нормативно-правових актів, положення яких регламентують низку інститутів цієї галузі, була прийнята зовсім в інших історичних 
умовах, ніж зараз, з урахуванням інших цінностей конституціоналізму, ніж діючих нині.

Цікаво, що у Пояснювальній записці до аналізованого проекту Закону про цей аргумент не згадується. Серед чотирьох аргументів, які навели автори проекту Закону № 1075 від 29 серпня 2019 року на користь необхідності прийняття цього документу, найближчим до наведеного вище є такий: «законодавство України та законодавство СРСР базуються на принципово різних засадах, що зумовлює їх концептуальну несумісність. 3 позицій сучасної нормопроектувальної техніки якість законодавства СРСР $€$ незадовільною, а застосовувана термінологія та підходи - застарілими» [10].

Варто було б пояснити, що це за «принципово різні засади», які викликають «концептуальну несумісність». Таке пояснення було б логічним у разі посилання на цінності конституційного права зокрема або сучасного конституціоналізму загалом.

На користь прийняття аналізованого проекту його автори наводили також і інші аргументи:

1. «Законодавство СРСР не є досить систематизованим. Наразі не існує єдиної бази законодавства СРСР, яка б забезпечувала вільний доступ зацікавлених осіб до відповідних актів. Проблемним є з'ясування остаточної редакції того чи іншого нормативноправового акта з урахуванням всіх внесених до нього змін і доповнень» [10].

У цьому аргументі автори проекту Закону № 1075 від 29 серпня 2019 року посилаються, ймовірно, на те, що існує такий вид систематизації законодавства, як інкорпорація, ведуть мову про те, що офіційна інкорпорація щодо вказаних актів не здійснюється Міністерством юстиції України та/або іншими органами публічної влади.

Але це не зовсім правильно. Можна навести приклади офіційної інкорпорації Житлового кодексу України, Кодексу України про адміністративні правопорушення, які неодноразово виходили друком у вигляді брошур. К.В. Головко запропонувала вважати домінантною та пріоритетною електронну форму офіційної інкорпорації законодавства [13, с. 216-221]. Прикладами електронної форми розміщення результатів офіційної інкорпорації Житлового кодексу України та Кодексу України про адміністративні правопорушення можуть бути відповідні веб-сторінки офіційного веб-порталу Верховної Ради України. Отже, цей аргумент не $є$ релевантним.

2. «Серйозні юридичні труднощі мають місце і в тих випадках, коли зміст нормативно-правового акта СРСР достовірно встановлено. Так, обов'язковою умовою його застосування є відповідь на питання, в якій частині такий акт не суперечить законодавству України. Відповідний аналіз потребуе залучення фахівців, вимагає серйозних часових і фінансових витрат» [10].

Цей аргумент також не є переконливим. Навряд чи варто покладати обов'язок проводити «відповідний аналіз» із залученням фахівців, який «вимагає серйозних часових і фінансових витрат», на суб'єктів правозастосування. Відповідні дії входять до компетенції органів публічної влади, які можуть скасувати застарілий нормативно-правовий акт у разі відсутності необхідності в ньому, а якщо документ є актуальним, то викласти його у новій редакції.

Якщо ж конкретний орган публічної влади не має відповідних повноважень, то він може повідомити про необхідність оновлення законодавства тому органу, який є суб'єктом правотворчості та/або законодавчої ініціативи. Це відповідає такій цінності конституційного права, як законність (А.Р. Крусян пропонує вести мову про «конституційну законність» [14]). Дотримання цієї цінності є важливим чинником практичної реалізації регулюючої функції галузі конституційного права України.

3. Останній аргумент є таким. «Практично не вирішуваними є юридичні колізії, які постають у випадках, коли певне коло суспільних відносин регулюється актами законодавства СРСР і не регулюється законодавством України. Так, відсутність нормативно-правового законодавства України зовсім не означає, що автоматично може бути застосовано законодавство СРСР, оскільки український законодавець може свідомо залишити відповідну сферу відносин поза законодавчим регулюванням, залишаючи на розсуд учасників таких відносин встановлення власних правил поведінки» [10].

Цей аргумент є не досить переконливим. Якщо в межах реалізації регулятивної функції конституційного права прийнято рішення не розповсюджувати ï охоплення на ту чи іншу групу суспільних відносин, то логічним і правильним буде почати з аналізу існуючої правової регламентації цих суспільних відносин, а в разі її застарілості та/або надмірності - внести необхідні корективи.

\section{Висновки}

У статті проаналізовано регулятивну функцію галузі конституційного права України, насамперед сучасні проблеми її реалізації. На прикладі законопроектної діяльності виявлено, як саме запровадити послідовну, без протиріч, реалізацію цієї функції в кон- 
тексті дотримання всіх сучасних цінностей конституційного права України зокрема та сучасного українського конституціоналізму загалом.

Зроблено висновок, що навряд чи регулятивна функція конституційного права може бути повноцінно виконана, коли досить вагома частина нормативно-правових актів, положення яких регламентують низку інститутів цієї галузі, була прийнята зовсім в інших історичних умовах, ніж діючі нині, з урахуванням інших цінностей конституціоналізму.

Перспективи подальших досліджень вбачаю в посиленні аргументації провідного характеру регулятивної функції галузі конституційного права України у порівнянні з його охоронною функцією.

\section{Список використаних джерел:}

1. Сінькевич О.В. Функції конституційного права та функції інших галузей права: порівняльно-правовий аналіз. Часопис Київського університету права. 2016. № 3. С. 105-108.

2. Сінькевич О.В. Основні напрями дослідження функцій i функціонування конституційного права (до постановки проблеми). Вісник Луганського державного університету внутрішніх справ імені Е.О. Дидоренка. 2016. № 2. С. 29-36.

3. Мішина Н.В. Органи самоорганізації населення в системі місцевого самоврядування. Нау кові прачі Наиіонального університету «Одеська юридична академія». 2019. Т. XXIII. С. 84-91.

4. Мішина Н.В. Конституційна скарга та індивідуальна заява до Європейського суду з прав людини як юридичні гарантії прав людини в Україні. Право України. 2018. № 12. С. 178-196.

5. Радько Т.Н. Теория функций права. Монография. 2014. 295 c. URL: https://books.google.com.ua/ books?id=yRlmAwAAQBAJ\&num=13.
6. Абрамов А.И. Проблемы реализации регулятивной функции права : дис. канд. юрид. наук. Н. Новгород, 2005. 222 с. URL: https:// www.dissercat.com/content/problemy-realizatsiiregulyativnoi-funktsii-prava.

7. Акт проголошення незалежності України від 24 серпня 1991 року. URL: https:// zakon.rada.gov.ua/laws/show/1427-12\#Text.

8. Про проголошення незалежності України : Постанова Верховної Ради Української РСР від 24 серпня 1991 року. Відомості Верховної Ради України. 1991. № 38. Ст. 502.

9. Про правонаступництво України : Закон України від 12 вересня 1991 року. Відомості Верховної Ради України, 1991. № 46. Ст. 617.

10. Пояснювальна записка до Проекту Закону про внесення змін до Закону України «Про правонаступництво України» щодо скасування дії актів СРСР та УРСР на території України, реєстраційний № 1075 від 29 серпня 2019 року. URL: http://w1.c1.rada.gov.ua/pls/ zweb2/webproc4_1?pf3511=66305.

11. Проект Закону про внесення змін до Закону України «Про правонаступництво України» щодо скасування дії актів СРСР та УРСР на теритоpiï України, реєстраційний № 1075 від 29 серпня 2019 року. URL: http://w1.c1.rada.gov.ua/pls/ zweb2 $/$ webproc4 1 ?pf3511 $=66305$.

12. Про порядок тимчасової дії на теритоpiї України окремих актів законодавства Союзу РСР : Постанова Верховної Ради України від 12 вересня 1991 року. Відомості Верховної Ради України, 1991. № 46. Ст. 621.

13. Головко К.В. Систематизація муніципального законодавства України: теорія та практика : дис. д-ра юрид. наук. Ужгород, 2019. 429 с.

14. Крусян А.Р. Конституційна законність у системі сучасного конституціоналізму. Актуальні проблеми держави і права : зб. наук. пр. Одеса : Юрид. л-ра, 2005. Вип. 25. С. 164-167.

Olena Sinkevych. Regulatory function of the Ukrainian constitutional law branch: current trends

The article analyzes the regulatory function of the constitutional law of Ukraine branch, first of all modern problems in its implementation. Among the internal functions of law, which reflect its substantive impact on public relations, appropriate regulatory and protective function of law should be considered. When researchers mention these functions, they always place them in this order - first a regulatory function, and then a protective function.

The importance of the regulatory function of law is difficult to overestimate, and the field of constitutional law of Ukraine is no exception. It is no coincidence that the regulatory function is "put forward", at the first place in the list, which always includes the protective function of law, and sometimes some others. After all, law is traditionally called the regulator of public relations, and this gives reason to focus on its regulatory function.

Given the importance of the norms of the constitutional law of Ukraine for the development of the national legal system, it should be emphasized that the regulatory function in the context of the studied area is more important than the protective function. In our opinion, this is due to a number of arguments, the main of which is the following: it is necessary to continue to point to Ukraine's rejection of the totalitarian past, the gradual and constant efforts of all public authorities to democratize public life.

On the example of draft law activities (the political party "Servant of the People" submitted to the Verkhovna Rada of Ukraine the Draft Law on Amendments to the Law of Ukraine "On Succession of Ukraine" to repeal acts of the USSR and Ukrainian SSR on the territory of Ukraine, registration 
№ 1075 of August 29, 2019), how exactly to introduce consistent, without contradictions, realization of this function in the context of observance of all modern values of the constitutional law of Ukraine in particular and modern Ukrainian constitutionalism in general.

In summary, it is unlikely that the regulatory function of constitutional law branch can be fully fulfilled when a significant part of regulations governing the provisions of a number of institutions in this area, was adopted in a completely different historical context than now, and therefore - taking into account other values of constitutionalism. Prospects for further research are seen in strengthening the argumentation of the leading nature of the regulatory function of the constitutional law of Ukraine branch in comparison with its protective function.

Key words: constitutional law, constitutional law as a branch of law, constitutionalism, functions of constitutional law, branch functions, functions of law. 